Ilgi Semin*, Dilek Ersil Soysal, Yasemin Seval-Celik, Murvet Hayran, Ayse Banu Demir, Ali Burak Ozkaya, Sevinc V. Inan and Gul Akdogan

\title{
Multidisciplinary case-based small group discussions to integrate basic medical sciences with clinical situations
}

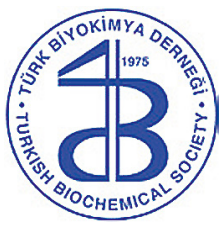

\section{Temel Tıp Bilimlerini Klinik Durumlar ile Entegre Etmek İçin Multidisipliner Olgu Temelli Küçük Grup Oturumları}

https://doi.org/10.1515/tjb-2019-0184

Received April 30, 2019; accepted August 23, 2020;

published online September 18, 2020

\section{Abstract}

Objectives: Integration of the basic medical sciences with clinical medicine motivates medical students by showing how the fundamental concepts they have learned will come into their future practice. In this context, we created clinical integration sessions (CIS) in our first-year medical curriculum.

*Corresponding author: Ilgi Semin, Professor, Department of Physiology, Faculty of Medicine, İzmir University of Economics, Sakarya Caddesi, No:156, 35330, Balcova, İzmir, Turkey, Phone: 90 232 4888301, Fax: 90232 2792626, E-mail: ilgi.semin@ieu.edu.tr. https://orcid.org/0000-0001-8747-5145 (I. Semin)

Dilek Ersil Soysal, Department of Internal Medicine, Faculty of Medicine, İzmir University of Economics, İzmir, Turkey.

https://orcid.org/0000-0003-0515-4300

Yasemin Seval-Celik and Sevinc V. Inan, Department of Histology and Embryology, Faculty of Medicine, İzmir University of Economics, İzmir, Turkey. https://orcid.org/0000-0002-6516-6285 (Y. Seval-Celik). https://orcid.org/0000-0003-4712-2366 (S.V. Inan)

Murvet Hayran, Department of Anatomy, Faculty of Medicine, İzmir University of Economics, İzmir, Turkey. https://orcid.org/0000-00016058-6304

Ayse Banu Demir, Department of Medical Biology, Faculty of Medicine, İzmir University of Economics, İzmir, Turkey. https://orcid.org/00000003-4616-8151

Ali Burak Ozkaya and Gul Akdogan, Department of Biochemistry, Faculty of Medicine, İzmir University of Economics, İzmir, Turkey. https://orcid.org/0000-0002-4811-2082 (A.B. Ozkaya). https://orcid.org/0000-0003-2395-1995 (G. Akdogan)
Methods: The instructors of different disciplines wrote the clinical scenarios together. The scenarios were discussed in five sessions with 39 first-year students. The first session's scenario consisted of four brief "anemia" cases. The next four sessions included a single case, according to the feedback of the students. Students formed groups of 7-8 participants. In the first $2 \mathrm{~h}$, the scenarios were discussed in the groups and questions were answered by the students. In the third hour, the instructors answered the questions together with the students. After the first CIS, written feedback obtained from the students via a survey.

Results: The survey provided positive feedback on the benefits of active learning within small group discussions, and most of the students thought that their background was sufficient to solve the cases, with some literature search. Conclusion: The scenarios, which provide multidisciplinary integration of basic medical sciences and clinical medicine, can be useful educational materials.

Keywords: active participation; basic medical sciences; clinical scenario; multidisciplinary integration; small group session.

Öz

Amaç: Temel tıp bilimlerinin klinik tıp bilimleri ile entegrasyonu, tıp öğrencilerini, öğrendikleri temel kavramların gelecekteki uygulamalarında nasıl kullanılacağını göstererek motive eder. Bu bağlamda, birinci yll tıp müfredatında klinik entegrasyon oturumları (KEO) oluşturduk.

Yöntem: Farklı disiplinlerden eğitmenler klinik senaryoları birlikte yazdılar. Senaryolar 39 birinci sınıf öğrencisi ile 
beş oturumda tartışıldı. İlk oturumun senaryosu dört kısa “anemi” olgusundan oluştu. Öğrencilerin geri bildirimleri doğrultusunda, sonraki dört oturum birer olgu içerdi. Öğrenciler 7-8 kişilik gruplar oluşturdu. İlk iki saatte senaryolar gruplar halinde tartışıldı ve sorular öğrenciler tarafından yanıtlandı. Üçüncü saatte eğitmenler, öğrencilerle birlikte soruları cevapladılar. İlk KEO'dan sonra öğrencilerden anket yolu ile yazılı geri bildirim alındı.

Bulgular: Anket, küçük grup tartışmalarında aktif öğrenmenin yararları hakkında olumlu geri bildirimler sağladı, ve öğrencilerin çoğu mevcut bilgilerinin, biraz literatur taramasıyla, olguları çözmek için yeterli olduğunu düşündü.

Sonuç: Temel tıp bilimleri ile klinik tıbbın multidisipliner entegrasyonunu sağlayan senaryolar yararlı bir eğitim materyali olabilir.

Anahtar Kelimeler: küçük grup oturumu; multidisipliner entegrasyon; temel tıp bilimleri; klinik senaryo; aktif katılım.

\section{Introduction}

In 1910, Abraham Flexner said: "An education in medicine nowadays involves both learning and learning how; the student cannot effectively know, unless he knows how" [1].

In the Clinical Education of Medical Students Report on Millennium Conferences I \& II by the years 2001 \& 2002, it was emphasized that the basic sciences were fundamental to clinical medicine, and that the curriculum had to be designed to integrate basic science and clinical medicine throughout the four years of the medical school [2].

Curriculum integration usually involves both horizontal and vertical integration. An integrated curriculum views learning and teaching in a holistic way and makes it interactive [3, 4].

Horizontal integration has linked different subject areas by bringing disciplines and topics together, and has enriched learning by these connections [3]. Vertical integration has brought basic and clinical sciences together, so that the basic sciences can be interpreted within clinical concepts during the years of undergraduate education [3]. Experiences showed that, the integration between basic and clinical sciences has the potential to improve motivation for learning, better understanding and longer retention of the knowledge [4].

In this context, the first year curriculum of faculty of medicine focused on the integration between different basic medical sciences and clinical sciences on the basis of cases. We arranged students into small groups to work together over the given cases and answer the corresponding questions under the guidance of instructors from different disciplines, including physiology, histology and embryology, anatomy, medical biology, biochemistry and internal medicine. After questions were answered by each group, then they were re-evaluated together with the whole class and instructors. These sessions were entitled as 'clinical integration sessions'- briefly 'clinical integration sessions (CIS)'. Previous reports have demonstrated that group discussions increase awareness towards erroneous reasoning, and help students in identifying gaps in personal knowledge [5]. This way, we believe the students will take the responsibility of their learning and be able to integrate the basic sciences knowledge in clinical practice. This, also, will make basic sciences more meaningful to the students in the medical context.

\section{Materials and methods}

In the 2017-2018 academic year, Izmir University of Economics Faculty of Medicine started to implement its curriculum, which included $3 \mathrm{~h}$ of CIS. The sessions followed lectures of the organ system-based organized basic medical science topics given by different departments in the course entitled, "Scientific Basis of Medicine".

CIS were planned to integrate the basic and clinical sciences on the basis of case scenarios. Learning objectives were defined for each CIS session, which all were consistent with the objectives of the SBM course. Cases were prepared by the instructors from above mentioned departments. The instructors worked together to generate questions that would enable the various basic science knowledge to be associated with the clinical situation of the chosen case. The educational material was created this way. Five CIS sessions were applied to 39 first-year students. Students were divided into five groups consisting of seven to eight participants in each group. Within the first $2 \mathrm{~h}$ of the sessions, students collaboratively read the case and answered the questions together within their groups in a structured way. Upon necessity, referrals were made to the resources required for the questions. In the third hour of the sessions, the instructors reviewed the cases and discussed the answers of the questions together with the whole class.

The first session's scenario included four brief "anemia" cases. After this session, verbal and written feedback were obtained from the students via a survey. The survey was evaluated by frequency analysis.

The students' feedback showed that a single case discussion would be better for each session. As a result, only one case was prepared for each of the following four sessions; "Respiratory distress syndrome", "renal failure", "multiple endocrine neoplasm", and "crush syndrome".

The case with "respiratory distress syndrome" was chosen as an example to be presented below.

Following the respiratory system related lectures and practices, which provided information from all disciplines, the same scenario was given to all groups.

The case was related to a premature newborn with respiratory distress syndrome. There was the history, physical exam findings and laboratory findings of the patient in the scenario. 
Questions about the case were as follows:

1) At which developmental stage were the infant's lungs when she was born? Describe the main features of the developmental stages of the lung. (Histology and Embryology)

2) Why are premature newborn prone to having respiratory distress syndrome? (Histology and Embryology)

3) List the main functions of the cell shown in the micrograph? (Histology and Embryology)

4) Why was this baby given endotracheal synthetic surfactant? Does it have an effect on the improvement of lung compliance? Explain in detail. (Physiology)

5) What are the mechanisms of grunting, nasal flaring, and sternal retractions observed in the baby? Which structures are related to these symptoms? (Anatomy and Physiology)

6) What is the mechanism of tachipnea observed in the baby? (Physiology)

7) According to the blood gas analysis, which type of acid/base balance disorder does she have? Explain the mechanism. (Biochemistry)

8) What kind of genetic mechanism can lead to respiratory distress syndrome? (Medical Biology and Genetics)

9) Taking advantage of the information provided, draw a diagram showing the mechanisms of the findings and the effects of the therapy.

The instructors are asked to describe their opinions about CIS process as well.

Ethical Considerations: The researchers obeyed the ethical rules and students filled the survey voluntarily.

\section{Results}

At the end of each session, students were asked to give feedback related to the learning activities. In the first session, written feedback was obtained and in the remaining sessions, verbal feedback was obtained from the students. 29 students out of 39 filled the survey voluntarily (see Table 1).

From instructors' point of view, the main outcomes of this process were as follows;

- The cases show students the importance of basic science knowledge in their future life

- Cases help the students learn the basic mechanisms better

Table 1: Questions and answers in the survey were as follows.

\begin{tabular}{lrrr}
\hline Question & $\begin{array}{r}\text { Poor, } \\
\%\end{array}$ & $\begin{array}{r}\text { Fair, } \\
\%\end{array}$ & $\begin{array}{r}\text { Excellent, } \\
\%\end{array}$ \\
\hline $\begin{array}{l}\text { Do you think the activity was } \\
\text { useful for your learning? }\end{array}$ & $13.79 \%$ & $24.13 \%$ & $62.06 \%$ \\
$\begin{array}{l}\text { Do you think group discussions } \\
\text { were effective for you to figure } \\
\text { out the case? }\end{array}$ & $13.79 \%$ & $31.03 \%$ & $55.17 \%$ \\
$\begin{array}{l}\text { Do you think your knowledge } \\
\text { was sufficient to evaluate the } \\
\text { case? }\end{array}$ & $21.42 \%$ & $60.71 \%$ & $17.85 \%$ \\
\hline
\end{tabular}

- Radiological anatomy and physical examination results of the case are good tools to prepare the students to clinical anatomy

- It is useful to see the whole picture and review the system before exam

- This technique is sustainable and appropriate for learning outcomes

- We choose the best case to integrate all of the disciplines, we work together and produce the most useful scenario

- I understand the expectations of colleagues and now I am organizing my lectures to give the necessary information for the other disciplines as well

- We produced a common language during this process and now we understand each other more.

\section{Discussion}

Small group active learning exercises provide the students a framework for analysis, synthesis, and application of basic medical science concepts relevant to clinical medicine [5]. In 1985, Safran and Yeasting published how they had designed a course for the first-year medical students to demonstrate the association between biochemistry and physiology content of the curriculum and applications of clinical medicine. They provided the integration of teaching among clinical and basic sciences instructors. This way, the students had the chance to encounter patients and clinical situations as early as possible and learn, read and evaluate literature independently [6]. Another publication by Duban et al., emphasized that, sessions supported by both related basic science audiovisual resources and clinical problems with questions obliged to students to reason through basic-science mechanisms, and integrating both teachers and concepts from basic, as well as clinical sciences could improve student attitudes toward the basic sciences [7]. In the case of problem-based learning (PBL) the educational activities begin with the PBL case, the students experience many features such as independent study before discussing their knowledge in the group, listening and recording, evaluating the literature and using resources, cooperation, respecting the colleagues' views [8].

Team-based learning, which we also use in our curriculum, is another form of small group learning applied in big classes by one instructor. It begins with previous learning activity, have essential steps, and the main goal is to master the knowledge and apply it to complex problems [9]. Berrocal et al. drew attention to the challenges of teaching to the first-year medical students, mentioned the difference in students' level of knowledge so that the instructors had to be careful about the order of the presented integrated material and that the learning objectives had to be appropriate for the 
students [10]. Survey results showed that most of our students thought that their knowledge was sufficient to evaluate the case with some literature search.

To conclude, CIS may be a useful teaching technique for medical students to integrate multidisciplinary basic science knowledge and learn the mechanisms underlying clinical situations.

Acknowledgment: This study presented in "FEBS Workshop on Molecular Life Sciences Education: Training Tomorrow's Scientists”, 5-7 September 2018, İzmir.

Research funding: None declared.

Author contributions: All authors have accepted responsibility for the entire content of this manuscript and approved its submission.

Competing interests: Authors have no conflict of interest regarding this study.

Informed consent: Informed consent was obtained from all individuals included in this study.

Ethical approval: The researchers obeyed the ethical rules and students filled the survey voluntarily.

\section{References}

1. Whitcomb ME. The AAMC Project on the clinical education of medical students. Clinical skills education. The Association of American Medical Colleges (AAMC). Association of American Medical Colleges and Carl J. Saphiro Institude for Education and Research. Harvard Medical School and Beth Israel Deaconess Medical Center; 2004:5 p.
2. Weinberger $S$, Whitcomb $M$. The AAMC Project on the clinical education of medical students: the clinical education of medical students report on millennium conferences I \& II; Association of American Medical Colleges and Carl J. Saphiro Institude for Education and Research Harvard Medical School and Beth Israel Deaconess Medical Center; 2001 \& 2002.

3. Atwa HS, Gouda EM. Curriculum integration in medical education: a theoretical review. Intel Prop Rights 2014;2:113.

4. Govindarajan S, Vasanth G, Kumar PA, Priyadarshini C, Radhakrishnan SS, Kanagaraj V, et al. Impact of a comprehensive early clinical exposure program for preclinical year medical students. Health Prof Educ 2018;4:133-8.

5. Hopper M, Tune J, Klabunde R. Small-group activity to reinforce the impact of valvular defects and heart failure on cardiac pressure-volume relationships. MedEdPORTAL 2018;14: 10675.

6. Safran M, Yeasting RA. A first-year, student-managed course to correlate basic sciences with clinical medicine. J Med Educ 1985; 60:793-7.

7. Duban S, Mennin S, Waterman R, Lucero S, Stubbs A, Wanderwagen $C$, et al. Teaching clinical skills to pre-clinical medical students: integration with basic science learning. J Med Educ 1982;16:183-7.

8. Wood DF. $A B C$ of learning and teaching in medicine. problem based learning. BMJ 2003;326:328-30.

9. Sagin F. Team-based learning (TBL) for improving the learning experience: engage students in teams, engage teams in class, engage the class in life. 41st FEBS Congress on Molecular and Systems Biology for a Better Life, Kusadasi, Turkey, September 03-08, 2016, FEBS J 2016; 283(1 Suppl):8.

10. Berrocal Y, Fisher J, Regan J, Christison AL. Dehydration: a multidisciplinary casebased discussion for first-year medical students. MedEdPORTAL 2018;14:10725. 